
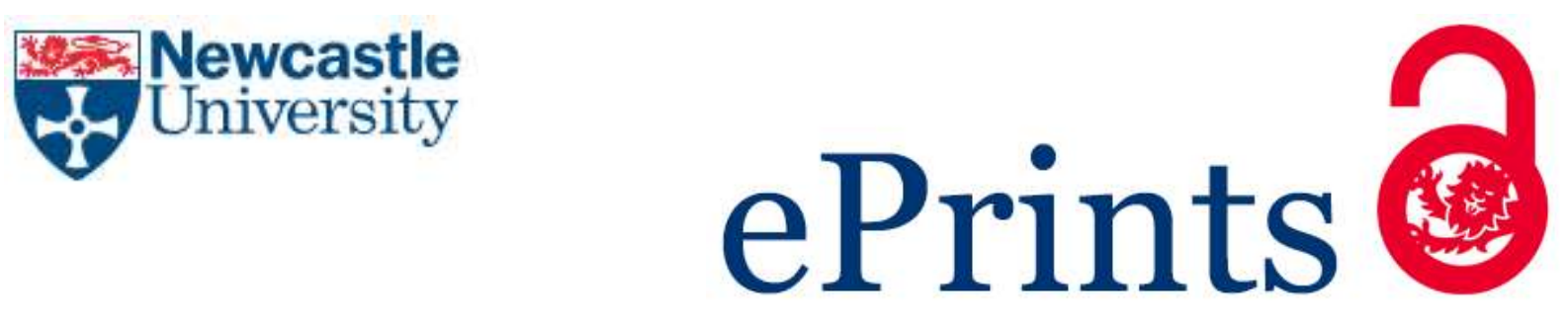

Smith HJ. Britishness as racist nativism: a case of the unnamed 'other'. Journal of Education for Teaching 2016, 42(3), 298-313.

\title{
Copyright:
}

This is an Accepted Manuscript of an article published by Taylor \& Francis in Journal of Education for Teaching on 25-05-2016, available online: http://dx.doi.org/10.1080/02607476.2016.1184461

Date deposited:

$07 / 06 / 2016$

Embargo release date:

25 November 2017

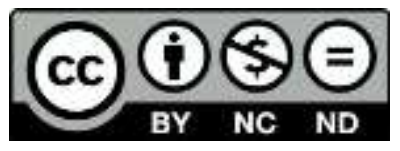

This work is licensed under a

Creative Commons Attribution-NonCommercial-NoDerivatives 4.0 International licence 


\title{
Britishness as racist nativism: a case of the unnamed 'other'
}

\begin{abstract}
The construct of Britishness, as with nationalism elsewhere in the world, although amorphous and permeable over time, continues to be used by politicians and the media as a powerful exclusionary force. Moreover in England, fundamental British values (FBV), its most recent and official incarnation, now holds particular currency in education policy and regulatory mechanisms. This paper employs the concept of racist nativism, developed to explain the dialectic relationship between nativism and racism in America, to analyse both political constructions of Britishness with media portrayals of this, and student teachers' comprehension of FBV as an aspect of the Teacher standards in England. The underlying premise here is that understanding student teachers' perceptions requires an understanding of the social context in which they are learning to teach. The paper explores relations between these; distinct differences between the manifestations of racist nativism in the socio-political context, compared to student teachers' perceptions in a professional context highlight perturbing issues for critical teacher educators. Furthermore, the two analyses support articulation of the operationalisation of racist nativism in a context outside of the specific racial context of America. As this is manifested in subtly but importantly different ways than previously considered, the analysis also offers elaboration on the concept of racist nativism itself.
\end{abstract}




\section{Britishness as racist nativism: a case of the unnamed 'other'}

We live in depressingly familiar times and yet patterns of discrimination, forever in flux, are perceptibly differently configured at present. Those fleeing war in Syria, military action in the Middle East or escaping grinding poverty, arrive on the shores of Europe to face instances of public resentment (The Independent, February 15, 2016), open media hostility and EU stasis. Whilst in the American search for a new president, the current Republican frontrunner advocates a moratorium on all Muslims entering the country and describes Mexican 'immigrants' as rapists and criminals (The Guardian, June 16, 2015). This global context, in which race, religion and immigration status (real and perceived) are interwoven to construct, name and vilify the 'other', requires nuanced social analysis. Racist nativism is a concept developed by American critical race scholars dissatisfied with the erstwhile limited White/Black dualism to examine more comprehensively the racialized lives of all people of colour in America (e.g. Galindo \& Vigil 2006; Lippard 2011). It attempts to examine and explain the co-existence of and dialectic relationship between racism and nativism. Pérez Huber et al $(2008,43)$ have defined racist nativism as:

'the assigning of values to real or imagined differences, in order to justify the superiority of the native, who is perceived to be white, over that of the non-native, who is perceived to be People and Immigrants of Colour and thereby defend the rights of whites, or natives to dominance.'

This paper examines racist nativism at play in England, by drawing on two sources: current political constructions of Britishness together with recent media portrayals (mostly printed and on-line newspaper sources); and student teachers' responses to a requirement within the English Teacher Standards that they uphold public trust by 'not undermining fundamental British values' (FBV). FBV is taken from the definition of extremism within the UK's 
Prevent Strategy, one arm of the government's overall counter-terrorism strategy,

CONTEST. Both sources are analysed by reference to racist nativism as conceived within critical race theory with critical understandings of whiteness, and as found manifested in practice in previous research.

The underlying premise here is that understanding student teachers' perceptions requires an understanding of the socio-political context in which they are learning to teach and concomitant policy changes. Further, as argued by van Dijk (1991, 1993, 2016), ideological understandings of race by the population at large, including therefore student teachers, are predominantly acquired and reinforced through verbal socialization alongside consumption of texts such as government publications and news reports (including the mainstream press). It is of course acknowledged that influence of newspapers will be mitigated and diversified at the individual level (van Dijk 2016). However, following over 2 decades of detailed critical discourse analysis (CDA), van Dijk $(2016,244)$ argues that control over these discourse sources lies with societal elites including politicians and newspaper editors, and he concludes that:

'the media as a whole define the internal structures, the points of relevance, and especially the ideological boundaries of social representations. They provide the ready-made models, that is the facts and opinions, that people use partly in what to think, but more important which they also use in devising in how to think about ethnic affairs.

It is therefore understood that student teachers' perceptions will be in some way influenced by the current socio-political context which includes the ideological boundaries of social representations marked and defined by politicians and the media. What is important here, is not to prove a deterministic relationship between students as readers/consumers and the 
political commentary and associated news reports they read/consume, but to describe the socio-political climate created by politicians and the media and to examine to what extent and how students' perceptions are reflective of this context, including, crucially, any differences between them.

In terms of student teachers' responses to the professional standard, the analysis provides a window into the particular way racist nativism can operate in this specific English professional context. The paper therefore also examines the ramifications of this for teacher educators wishing to educate student teachers for transformative practice. Together the two analyses support articulation of the operationalisation of racist nativism in a context outside of the specific racial context of America. As this is manifested in subtly but importantly different ways than previously considered, the analysis offers elaboration on the concept itself. The analysis may also prove a fruitful addition to the investigative armoury of scholars examining the social context of Britain in light of the current global context. Before going further, it seems expedient to more closely define current conceptions of racist nativism.

\section{Racist nativism}

Higham's $(1955,4)$ influential book, 'Strangers in the Land' which traced patterns of American nativism from 1860 to 1925 concluded that nativism ought to be defined as 'intense opposition to an internal minority on the grounds of its foreign (i.e. un-American) connections.' He revealed three forms of nativism over this period, which he named antiCatholicism; anti-radicalism; and racial nativism in which 'the concept that the United States belongs in some special sense to the Anglo Saxon 'race', offered an interpretation of the source of national greatness.' (9). We ought to tread carefully, however, in assuming an unproblematic intersection of racism and nativism as, for one thing, their end goals differ: 'the goal of nativism is to justify and reward the superiority of the 'native' and racism's goal 
is to reinforce 'White' superiority' (Lippard 2011, 595). As a consequence, they also differ in their demands in that nativism requires assimilation 'through the elimination of undesirable cultural, linguistic and religious or political traits' whereas racism demands 'exclusion from the dominant culture' (Galindo and Vigil 2006, 425).

Racism and nativism can and do collide however. Within the history of racial nativism identified by Higham, 'whiteness was privileged because it became strategically equated to Anglo-European heritage, Western religious traditions, and other values and beliefs deemed dominant and supportive of the 'American spirit'.' (Pérez Huber et al 2008, 42). Whiteness is understood as 'the discourse, the culture, the structures, the mechanisms, the processes, the social relations ... that produce racialized subjects including whites' (Levine-Rasky 2000, 285), and its modus operandi is the reproduction of white identities and interests in order to maintain a position of structural advantage. Relatedly, Omi and Winant $(2015,129)$ define racism beyond individuals' beliefs and attitudes as also and necessarily involving 'the production and maintenance of social structures of domination'.

Racism and nativism converge therefore, when we consider both as mechanisms operating to justify the perceived superiority of whites as natives, thereby reproducing and reinforcing the existing hegemony. Employing a racist nativism framework reveals not only the racialization of immigrants to shape anti-immigrant attitudes but also how perceptions of racial differences 'construct false perceptions of people of color as 'nonnative'” (Pérez Huber 2011, 382). Importantly, it also reveals 'the implicit manifestation of this ideology within institutional practices to protect White privilege and oppress immigrant minorities.' (Lippard 2011, 600). In short, racist nativism is a useful tool for examining social influences on (changes to) institutional practices such as education policy. But, to borrow Ladson-Billing's (1998) turn of phrase, what is it doing in a nice field like English teacher education? 
Research has revealed that nativism is driven by a defensive nationalism (Galindo \& Vigil 2006) which arises particularly 'during times of national crisis ... These national calamities usually include economic downturns, wars (or even terrorist attacks), or sudden increases in visibility due to the size or concentration of immigrant populations.' (Lippard 2011, 593). This perfectly describes the current British situation as conceived by politicians and as presented in the media. A large scale research project (RASIM) investigating discourses associated with refugees, asylum seekers and immigrants in UK press found a steady increase of related articles from 1996 to 2006 (KhosraviNik et al 2012); given world events since 2006, it seems likely this trend has continued. Consequently, although the history of racial struggle in UK is not the same as in America, it is arguable that the particular confluence of current world events including mass migration, together with associated media attention, has led to more instances of racialized strife being due to 'the nationalistic anxiety of the times' whilst nativist fears are increasingly crystallized 'into racist doctrine' (Lippard 2011, 598). A perfect example of the dialectic between racism and nativism proffered by a member of the elite with access to media attention, emerged in a very recent interview in The Daily Mail (April 10, 2016) with Sir Trevor Phillips (former Head of the UK's Equality and Human Rights Commission). He describes extremist views as flourishing amongst British Muslims who live in 'a nation within a nation'. His solution is ethnic monitoring so that housing estates don't become 'ghetto villages', and schools have 'no more than 50\% Muslim or other minority pupils'. Note he is not suggesting that the number of white pupils or pupils of faiths other than Islam be restricted in order to encourage social integration.

To understand more about how racist nativism functions, in order to apply it to the British context, it is useful to draw on previous research undertaken to identify the operationalisation of racist nativism as sentiments (Sanchez 1997); accusations (Jaret 1999 in Lippard 2011); and discourses which Pérez Huber $(2011,382)$ defines as "the institutionalised ways we 
perceive, understand and make sense of contemporary US immigration, which assigns values to real or imagined differences, that justifies the perceived superiority and dominance of the native (whites) and reinforces hegemonic power". The findings of these studies are combined and summarised thematically in the table below and are henceforth used to uncover the manifestations of racist nativism in constructions of Britishness by politicians and in the mainstream UK press.

[Table 1 near here]

\section{Method I: identifying political commentary and press articles}

The aforementioned large scale RASIM research project revealed that of the 170,000 articles uncovered, there were peaks of interest in reports about refugees, asylum seekers and immigrants and these related to global events, such as 9/11 (KhosraviNik et al 2012). In a similar vein, the political texts and media sources drawn upon in this study over the period from 2013-2106 arose during events of some national interest as summarised below:

Event 1: June $2014-799^{\text {th }}$ anniversary of the Magna Carta.

Event 2: January 2015 - Charlie Hebdo attack in Paris.

Event 3: 2015 onwards - migrants arriving on European shores begins to be consistently and widely constructed in the press as a 'migrant crisis'.

Event 4: October 2015 - Conservative Party Conference

Event 5: July 2015 - Calais Crisis as holiday makers' travel on Eurostar is delayed as migrants attempt to reach UK in the Channel Tunnel.

Commentary from politicians included in this paper is generally reproduced as articles in a range of newspapers and so the full spectrum of newspapers are drawn on here, from broadsheets (liberal to Conservative) to tabloid press. 


\section{The politics of Britishness: versions of racist nativism}

In order to understand the role racist nativism plays in current political and media constructions of Britishness today, it is useful to begin with a brief commentary on its recent history. The history of nationalism is contested (see for example, Colley 1992), but, at least as far back as Mosley's British Union of Fascists in 1930s and 40s, the plurality of Britain has been cast as a threat to the nation. Manichean constructions of 'us' versus 'them' have situated some as enemies both within and without the nation. The election of New Labour in 1997 continued this trend, with a sustained attack on multiculturalism emerging after the urban disturbances in some Northern towns in 2001, as the cause of assumed segregation within society.

Research into media's constructions of 'others' begins in earnest with the aforementioned seminal research into racism and the press by van Dijk $(1988,1991,1993)$ which revealed that although the coverage gradually became less overtly racist, 'stereotypes and the definition of minorities as a 'problem' or even as a 'threat' is still prevalent' (van Dijk 1991, 260). The RASIM project examined the representation of refugees, asylum seekers and immigrants in British media from 1996 to 2006 by employing a combination of corpus linguistic analysis of large data sets with CDA (for example: Baker et al 2013; Blinder and Allen 2016; KhosraviNik 2009, 2010, 2014; KhosraviNik et al 2012). The sophisticated analysis revealed the tabloid press at ease in reproducing or 'harvesting' existing negative attitudes and prejudices, whereas the conservative broadsheets were more sophisticated in their xenophobic representations. They also found the liberal press, although more positive, acted to essentialise 'others' as victims, thereby doing little to counter such negative representations. 
Post 9/11 and the London 7/7 attacks, some communities, chiefly Muslims, began to be situated by politicians as responsible for a presumed lack of societal cohesion (so-called 'self-segregation') and hence particular groups were viewed as a greater danger to national security with an attendant responsibility for changing this (Kudnani 2007). As Kudnani wisely foresaw, this presumed self-segregation of Muslims encouraged a slippery slope from assumptions about segregation, to extremism, to terrorism. Research into the press construction of Muslims between 1998 and 2009 found that Muslims were mostly constructed as an homogenous group connected to conflict (Baker et al 2013). The research found that both negative and well intentioned articles contributed to a process of 'othering' where Muslims are presented as existing in tension with the UK or 'the West'. Further research post 9/11 revealed that the press distinction between moderate Muslims and radical Islamists had the effect of constructing the Muslim community in general as 'a two-faced Janus, with the law abiding always defined in relation to extremists' (Nickels et al. 2012, 352). Perfectly in tune with political commentary of the time, this "narrative served to frame British Muslims as the constitutive other and the source of the threat posed by contemporary terrorism, placing the burden of challenging violent extremism squarely upon the shoulder of Muslim communities' (Matthews 2015, 270).

This brief sojourn into political and media texts driven by 'elite racism' paints a picture of the ideological boundaries of social representation (van Dijk 2016) within the socio-political context up to the present day, thereby supporting a closer examination of constructions of Britishness from 2013-2016.

After the Charlie Hebdo massacre in Paris, Eric Pickles (Department for Communities and Local Government 2015) (my italics), the then chairman of the Conservative party, sent a letter to every mosque in the country (to over 1,000 Imams) saying: 
'You [Muslim leaders], as faith leaders, are in a unique position in our society. You have a precious opportunity, and an important responsibility: in explaining and demonstrating how faith in Islam can be part of British identity. ... We know that acts of extremism are not representative of Islam, but we need to show what is.'

The presumed tension between being both Muslim and British, requires what Cameron (Cameron 2014) has called the ‘muscular promotion' of British values, which:

'have a vital role to play in uniting us .... As I've said before, this [lack of a belief in democracy, equality and tolerance] has not just led to division, it has also allowed extremism - of both the violent and non-violent kind - to flourish'.

So Muslims continue to be positioned as an homogenous entity, given primary responsibility for countering extremism. The perceived threat to the nation is now explicitly marked however, by a disjoint between Western values and Islam, where the term values is a marker for 'the British way of life', and muscular assertion of Britishness, also construed in terms of values, is sin qua non the solution to Muslim aggression. The narrative of values gains primacy and is framed as both problem (individuals and groups are perceived as not holding the same values as the nation as a whole) and solution (integration for national security requires the vigorous promotion of the nation's values defined by politicians as social elites). Britishness is crystallised into a discourse of values.

During the same period, there is an ongoing refusal by European countries to provide a collaborative solution to the increasing numbers of people fleeing war and poverty landing in flimsy boats on the outer regions of Europe's shores, or dying at sea trying to reach Europe. Media reports of such incident are sometimes harrowing but often hostile and disdainful. An example is an article published by The Daily Mail (May 27, 2015), in which the plight of immigrants, who were described as straggly, grubby looking, and filthy, was juxtaposed with 
and overshadowed by the reported concerns of holiday makers in Kos, who were made to feel 'awkward' and 'uncomfortable' by the sight of such misery. Such reports, (for example: The Mirror (September 2, 2015)) often acknowledge European governments' response, or lack thereof, to the crisis. Reactionary politics to the crisis was also evident in Teresa May's speech to the Conservative party conference in October 2015, in an effort to argue against increased acceptance of the migrants to the UK:

'[B]ecause when immigration is too high, when the pace of change is too fast, it's impossible to build a cohesive society. ..... And we know that for people in low-paid jobs, wages are forced down even further while some people are forced out of work altogether.' (Printed in full in The Independent (October 6, 2015)

Immigrants (both European and Non-European) who are outside the nation trying to enter are positioned as dangerous; culturally in terms of a threat to social cohesion, but also economically as a threat to natives' wages and job security, echoing racist nativist discourses in America. The number of immigrants arriving into Europe 'en masse' is also of concern here. In July 2015, talking about the Calais crisis, Cameron described immigrants attempting to come from North Africa to Europe via the Channel Tunnel as a 'swarm of migrants'. Such representations of immigrants also occur in the tabloid media: The Sun newspaper's article (October 6, 2015) by Katie Hopkins in which she compares immigrants to norovirus is a particularly vicious example. Although some might argue Katie Hopkins is an extreme example, the fact remains that The Sun, a national tabloid newspaper with a considerably large readership, chose to print this article, which, because of the author's notoriety has since been discussed in other media sources, making its possible impact even wider. Employment of metaphors such as marauding, swarming, and flooding, acts to dehumanise immigrants through animalisation as vermin or disease. This trend identified by Steuter and Wills (2010) 
is disturbing because this particular animalisation intimates eventual eradication. It also has long term effects upon social actors, including of course student teachers, because the 'mainstream proliferation of such language has the effect of justifying it; such phrases come to seem like simple, natural descriptions rather than motivated symbolic choices that perform significant ideological work.' (156). It also appears to mark a subtle shift from the less overt racism identified by van Dijk's earlier research (1991) as well as the more recent racialisation of innuendo and inference revealed by Fox et al $(2012,690)$ in tabloid media presentations of Hungarian and Romanian and Roma European immigrants up to 2009, towards more overtly racist presentations.

Moving into 2016, we are now witnessing reports of what one could argue as the inevitable consequence of the prioritisation of the securitisation agenda over concerns about racism and Islamophobia; for example, the apparent policy of a security company G4S (who are employed by the Government to house those claiming asylum in the North-East of England), to paint red the doors of those claiming asylum currently residing in one northern town. Residents of these houses reported being targeted with both verbal and physical abuse (The Guardian, January 20, 2016). As Kudnani $(2007,34)$ put it racism has come to be 'understood as an outcome of segregation, not its cause.'

At the outset of 2016, we are also witnessing a sustained and deliberate targeting of Muslim women by Conservative integrationist policy. In announcing the sudden re-availability of money for English classes, Cameron specifically highlighted the number of Muslim women not yet able to speak English, whilst also suggesting those who didn't speak English were more susceptible to extremism (The Guardian, January 18, 2016). Cameron added: 'some of these people have come from quite patriarchal societies and perhaps the menfolk haven't wanted them to speak English'. On $5^{\text {th }}$ February 2016, Amber Rudd, the Conservative energy 
secretary, supported Cameron's claims in the television programme Question Time. She argued:

'If the mother can't speak to the child then it's going to be difficult for her to communicate the very strong British values that we've got and I think we have to be careful about not pussyfooting around the fact that British values are important and are something that we shouldn't avoid. Sometimes the Left is a bit too much saying we mustn't interfere with these cultural areas; we should participate, we should say that we recognise there's a problem here which is Muslim women who need to have language skills and we should concentrate the resources.'

This demonstration of the conflation of first languages other than English (of 'immigrant' families), with culture/race, and with religion (Islam), all of which is constructed as problematic, helps us to identify those overtly 'othered' as a threat to British values or the British 'way of life'. The term 'pussyfooting around' is also suggestive of claims of white victimhood within racist nativism.

There is no escaping the imperialistic presumption of superiority in the above manifestations of Britishness, and this latest development is no exception. Here British values are constructed as more modern and civil in comparison to Muslim values (as signalled by Muslim women's requirement for permission to learn how to speak English), with the suggestion therefore that at an individual level 'British' men are more liberal in their views towards women, whilst 'Muslim' women are more passive than their 'British' counterparts, imitating earlier conflations of the West with 'modernity and global mastery' (Bonnett 2008, 25). Furthermore, there is also no escaping that 'the identifier for prejudice and discrimination is no longer confined to race, color, or nationality, but extends also to religion' Rivzi $(2005,171)$. Nowhere is this clearer than in the speech given by David Cameron 
(Cameron 2011) on $11^{\text {th }}$ February 2011 whilst in Munich (the same day of a large antiMuslim march by the English Defence League in Leeds), in which there is swift slippage from multiculturalism to race to Islam to extremism, all within the space of about 150 words. In this speech he clearly demarcates the 'us' (signalled by use of the personal pronoun 'we') as whites (a term he uses), who are presented as the victims of unevenly applied charges of racism (which is described as the holding of objectionable views), mirroring the racist nativist sentiment of white victimhood. In contrast 'others' are marked by references to those of 'different' cultures who are separated from the mainstream, and Muslims who are criminalised in their assumed association with extremism. For an excellent analysis of this speech containing the speech in full, see Gilroy (2012).

Racist nativism is therefore alive and well in British media and politics today: immigrants are subtly and sometimes overtly racialized, whilst certain ethnic and religious groups are cast as troublesome in their failure to integrate and to hold British values, thereby undermining their credibility as natives. The 'other' (the criminal, the dangerous, the drainer of resources, and the person who is a threat to British societal cohesion, security and to 'us', the superior white, non-Muslim, native) is explicitly named as non-white immigrants (those arriving), those whose families have at some earlier stage immigrated to UK with a 'different' cultural heritage, and Muslims. It appears, therefore, that Higham's nativistic concern with religion is of significance in any understanding of racist nativism at play in England today, as adherents to the Muslim faith have become 'dangerously foreign agents' to British life. But, what impact has all of this this had on education policy specifically?

\section{Britishness and education: towards racist nativism via FBV}

Profound changes to education policy in relation to Britishness and British values in particular, are very recent. Up to 2014 Britishness as a political construction had not had a 
direct impact on schools or schooling in England: the only relevant documentation was DfE guidance entitled 'Learning together to be safe: toolkit for schools' published in 2008 by the Labour government. This now seems like the calm before the storm. In March 2014, Ofsted (the UK's school inspectorate) and Birmingham City Council (BCC) reported that they were about to inspect several schools in Birmingham (most with significant numbers of Muslim pupils, and some with predominantly Muslim leadership teams) following what is now presumed by many to be a hoax letter claiming a Muslim plot to overtake schools in Birmingham. 21 schools are investigated in May 2014 as pupils were about to sit their national exams. In June 2014, Ofsted reported 'an organised campaign to target certain schools' and Ofsted chief Sir Michael Wilshaw was reported as saying 'a culture of fear and intimidation has taken grip' in Birmingham schools caught up in the Trojan Horse affair (BBC, June 9, 2014). Following this report, there were two further reports (Kershaw for BCC and Clarke for DfE) both of which revealed no evidence of extremism in any of the schools. Kershaw reported some governance issues and Clarke's concerns were reported by Nicky Morgan (the new Education secretary) to parliament:

'There has been no evidence of direct radicalisation or violent extremism but there is a clear account in the [Clarke] report of people in positions of influence in these schools, who have a restricted and narrow interpretation of their faith, not promoting British values and failing to challenge the extremist views of others'.

The government's reaction to Ofsted's initial claims was swift, and in early June 2014, Michael Gove (the Education secretary) announced the government would 'put the promotion of British values at the heart of what every school has to deliver for children'. In November 2014 the Department for Education published advice for maintained schools on Promoting FBV as part of Spiritual, Moral, Social, and Cultural Development (SMSC). This was followed by changes to the Ofsted requirements for inspection in October 2014: to be graded 
as outstanding by Ofsted, schools must demonstrate that 'the promotion of fundamental British values, [is] at the heart of the school's work'. In February 2015, the government published a new Counter Terrorism and Security Act (2015), under which teachers have a legal duty to prevent people from being drawn into terrorism. This has led to organisations including companies and consultancy firms, providing WRAP (Workshops to Raise Awareness of Prevent) training, so that school staff can develop expertise in recognising individuals who are vulnerable to being radicalised. Cameron's most recent attack on Muslim women has had immediate ramifications for schools as Ofsted chief Sir Michael Wilshaw said that school inspectors will be allowed to rate schools as 'inadequate' if they allow face veils (BBC, January 26, 2016).

This rapid insertion of counter-terrorism work combined with statutory requirements to teach British values (accompanied by legal and regulatory powers) has changed the face of education policy. The exact nature of how such changes have been interpreted by schools is not yet known. However, the statistics for referrals to Channel, the government's antiradicalisation scheme are shocking: half of all of referrals of children in 2015 now come from schools, an increase from $8 \%$ in 2012-2013. This means 'more than two pupils are now referred every school day' (Dickens 2015, 8).

And so, the question remains, what is the impact of such policy changes on student teachers entering the profession in the midst of this 'othering' maelstrom? The data used to answer this question arises from an analysis of responses from Primary PGCE students to the questions: What do you understand by the requirement for "not undermining fundamental British values" in the personal and professional conduct section of the standards? Do you have any comments about this requirement? Students have been asked these questions close to the outset of their course for three years from 2013 to 2016. 


\section{Method II: collecting and analysing student responses}

The student teachers in this study are enrolled on a one year Postgraduate Certificate of Education (PGCE) course located in the North East of England. It is open to all students, home and international. The cohorts are usually a mix of students from all over Britain and some from Ireland, however, the vast majority are white and most are women, although there are more men than the sector average. Many are local to the region the university is situated in, which is a less racially diverse region of England. In fact, this is not dissimilar to the teaching profession as a whole in England which remains stubbornly white. The latest DfE statistics show that only $7 \%$ of the teacher workforce are from a Black or minority ethnic background.

Students are asked the questions (as above) as part of an audit they complete about their prior experiences of linguistic and ethnic diversity; they are aware the subject leader uses the audit to support their development on the course, i.e. to determine what they need to learn.

Students complete the audit during their own time leaving less space for the cross-fertilisation of ideas. Although completion of the audit is compulsory, these final questions are optional. The rationale for doing this was entirely pragmatic: in 2012-2013 many students had never even heard of the term FBV, and so optionality for this question was presumed to support swift return of the audit. The returns in that first year (2013-2014) proved so interesting that the questions remained on the audit for the following two years and in the original form for comparison. The total number of audits considered here is 91 consisting of $48 / 90(=53 \%)$ audits returned in $2103 / 2014 ; 25 / 43(58 \%)$ the following year; and 18/31 (58\%) this year. It is acknowledged therefore that this constitutes a small sample size.

In interpreting the responses, one must acknowledge the power differential between student and teacher. It would be naive to imagine all responses were neutral. Although the question is 
relevant to the audit as it refers to a Teacher Standard, it is probable that students would still wonder why they were being asked this question by this person. It is likely there would be a range of reactions including wanting to please or impress the tutor. Knowing how to do this may make the student search out the tutor's publication record, or make assumptions based on their experiences so far of the tutor's ideas, pedagogic style, or even, their political persuasion. Consequently, one cannot assume that the audits reveal what individual student teachers actually think about FBV. However, given the student tutor relationship, it is highly likely that students will expect their responses to be acceptable to the tutor. Also, one can say that whatever the students' motivation for the content of their response, that content is still interesting as the knowledge it reveals must have originated somewhere. In effect, therefore, given van Dijk's (2016) assertion as to the role of media in influencing ready-made models of facts and opinions relating to 'racial affairs', the student responses do tell us something about the mainstream discourses prevalent in our society, and hence we can see if this is reflective of the discourses prevalent in the media and politics.

Moreover, whatever conclusion they reach as to the content of their response, all students are likely to perceive the manner of their response to require professionalism: the relationship between tutor and student is a professional one and students are made aware from the outset that the course requires professionalism and professional behaviour is an expectation. In short, once they have established the content of their response, which is likely to be viewed as professionally acceptable content, they must then determine how to phrase it as a professional. This is a crucial aspect of the research as we shall see later in the analysis.

There were three stages of analysis. Firstly, responses from the first year's cohort were analysed to reveal emergent basic themes such as 'FBV acts as guidance for curriculum content'. These themes were then elaborated upon and extended in the same analysis process 
for the following two years' cohorts. The second stage involved collating and summarising these themes and placing them together for comparison. The third stage was to analyse the themes and their linguistic presentation in light of racist nativism as conceptually constructed and as manifested in practice in previous research in the US context. This facilitated consideration of whether the responses were reflective of the racist nativism pervading the social and political context as described above and/or associated policy developments.

\section{Initial Analysis}

The early stage of analysis revealed a wide spread of student understandings, with the largest percentage response being the 50\% of students in 2013-2014 who wrote an uncritical assertion of FBV as signifying justice, freedom, democracy, equality, free speech and so forth. Perhaps unexpectedly, fewer responses were wholly uncritical than those which included some level of criticality (around 65\%, double the number of uncritical responses), and some responses were wholly critical:

'Possibly they [FBV] might include: a neo-colonial outlook; the belief that we are somehow superior to the rest of the world purely based on being born in a particular geographic location; and a strangely oxymoronic obsession with security and liberalism.' (2014-2015).

In terms of changes identified over the 3 years, there is a steady decline in the number of students claiming they are unaware of the meaning of FBV and in those who express discomfort with the phrase, suggesting the media coverage of the Trojan Horse affair and changes to education policy have made some impression upon those entering the profession To understand this more precisely, a closer examination is required.

\section{Racist nativism as a signifier for Britishness without naming the 'other'}


One of the most fascinating aspects of the analysis is the lack of a name attached to the 'other'. There was no mention anywhere of immigrant/migrant, asylum seeker, or refugee in any of the responses. There was only one reference to 'Muslim' overall and that was by a student whom we shall name Jean (not her real name) who carried out considerable research into the meaning of the term FBV leading her to read the Prevent Strategy. In doing so she quotes a section from Prevent about Muslim supplementary schools. Two students employ the term Islam (both in 2013-2014), and neither usage implies 'otherness' in the sense explored here. The only term which is used in this sense is EAL (English as an additional language) an example of which we shall see shortly, but even this only happened once in 2013-2014 and once in 2015-2016. There were 10 mentions of the terms extremist/extremism and 9 of the terms terrorist/terrorism, but these were all within Jean's exploration of the Prevent strategy. Discounting Jean's response therefore, these terms were not used at all. A handful of students used the term minority ethnic (or ethnic minority), but again not to signify 'otherness' in a pejorative sense. There were no mentions of the term 'Black' and only one mention of the term white in this critical response: 'It implies that anyone who is not fundamentally British (i.e. white British if taken to the extreme) could be undermining these values.' Students more freely used abstractions via abstract collective nouns such as race, ethnicity and religion, and these mostly appeared in a list; for example "respect to those of all backgrounds (whether religious, racial, ethnic, etc.), even if their views or beliefs do match yours" (2015-2016, my italics). I shall use henceforth place some words in italics to highlight lexical choice and grammatical features of interest.

What makes this finding more interesting, however, is the fact that the students did signal, often quite overtly, perception of an 'us' and 'them' dichotomy in both uncritical and critical responses, as exemplified above. This was manifested in grammatical choice via personal pronouns as in this example: 'I think it is important to consider the way different cultures 
integrate into our society but also how accepting we are of them too' (2014-2015). In the majority of cases, as in these examples, otherness is attached to some unspecified, nebulous culture, race or religion, but there is one example, wherein otherness is suggested more clearly by reference to what it is not:

'I would imagine that what the term 'fundamental British values' is referring to are not specifically 'British' values but perhaps steeped in Christian morals and what most people would consider the morals and values of everyday life." And later: "a school community may comprise a whole range of ethnicities and people who identify themselves as being from other nationalities other than British' (2014-2015).

In effect, therefore, Christian morals are at the centre of the 'us', and, by implication, the 'other', signalled clearly by the expression 'other than British', are those ethnicities and nationalities that are non-Christian.

Once the 'us' is grammatically marked, students tend to position those who constitute the 'us' as superior, replicating political and media presentations discussed earlier, and, as exemplified by use of the verb 'strived' in this response: 'I understand that this comment relates to a standard of equality which in the most recent century the British people have strived towards.' (2013-2014). There are also a few examples which may be construed as part of the associated narrative of white victimhood, such as: 'I just think that in the same way that if I was to go to another country I would make every effort to participate in their culture, the same should stand for children with EAL coming to Britain' (2015-2016); the implication here being that this doesn't happen, and if 'we' have to do it then so should 'they'. This concern for English language learning mirrors the racialisation of language in America (e.g. Macedo \& Bartolomé 2014; Pérez Huber 2011) and Cameron's latest remonstrations about links between English language learning and terrorism. 
Although unnamed, the need for 'others' to assimilate into the dominant culture was more overtly expressed as in: "always keeping the focus on the British way of teaching things. So I think some schools say we should celebrate other cultures, but this statement means children of other cultures should learn to adapt to the British culture." (2013-2014). The following response is included at length to demonstrate how the empty spaces around the 'us' of FBV are filled by positioning Britishness as superior and normal, thereby requiring those children and families who are perceived as 'other' to be balanced out by the teacher who is one of 'us'.

'I think it is important to teach children about the rule of law, democracy and other systems in place in the country in order for them to understand the world in which they live. Although I do not believe these systems are perfect, an unbalanced approach to informing children of these topics may enshrine values within them which mean they do not fit into normal society in later life. .... Similarly if negative perceptions of British values are voiced in the children's home, it would only be fair that a teacher provided an alternative view ...'(2013-2014)

'Others' were also occasionally construed as a danger to national security, indeed the lengthy response above is suggestive of some deviancy on the part of some children's families. In the following example, security is linked to 'population change':

'I think the government intend to ensure that as a teacher in Britain I would always reinforce .... that the laws our country has laid down for us are there for our benefit, in order to reinforce the nation as somewhere safe to live. Perhaps this is the government's way of trying to ensure that as the dynamics of our population change the 'integrity' of this paradigm of Britain will be maintained' (2013-2014) 
A threat to the 'British way of things' as one student put it was also visible by implication in a very few responses, such as: 'I appreciate that within these concepts there may be challenges from different cultures and faiths, for example the equality of women, marriage and homosexuality.' (2013-2014). The choice of examples here is interesting as it is suggestive of some unnamed culture and religions as less modern with echoes of David Cameron's recent attack on Muslim women.

Finally, there are a handful of responses which suggest the 'other' as a drain on resources, most suitably captured by the lexical choice 'expense' in this response: 'To recognise and honour each child's ethnicity within the classroom but not at the expense of disregarding British values, it is important to acknowledge and sustain British values within the classroom.' (2013-2014).

In essence, therefore, the racist nativist discourses apparent in the students' responses demonstrate how the term FBV is a signifier for the 'what' and 'who' of Britishness. Nouns used as a proxy for values which signal that which constitutes the 'us' include: standards, acts and principles as applied to abstractions such as freedom, equality and democracy; and as habits, traits, and ways, as applied to individuals. The 'who' of Britishness, constituting the 'us', are those who hold these values and do the tolerating of 'others', and in so doing, are superior. Britishness as construed is also a signifier for the 'what' (the unnamed religions, races and cultures) and the 'who' of the 'other'; those who are not quite British enough and hence need to assimilate, feel more connected, learn to speak English, and become 'normal'; those who do the respecting of 'us'; and those who are a danger to 'us' and a drain on our resources. They are the unnamed empty spaces around the 'us', marked grammatically and distinguished as 'other' mostly through implication of the 'what' and 'who' is not 'us'. The purposeful choice by those entering the teaching profession to avoid naming the 'other', whilst clearly signalling the other exists in their imagination, seems an important addition to 
the manifestation of racist nativism revealed thus far in America and as we have seen, it lies in stark contrast to the choices made by some British politicians and journalists. It is perhaps a consequence of the way in which nativism and racism co-exist as mechanisms of the reproduction of whiteness, which, as considered below, often works to silence discussions about race and racism. Hence it ought too to strengthen our awareness of white supremacy as the impetus of both concepts, and, to borrow from Gordon Brown's patriotic fervour, as the golden thread which weaves together the manifestation of these concepts in practice.

\section{Concluding thoughts: hopes and fears for teacher education}

This study affords teacher educators hope in the number of students who are, even at this early stage of the course, thinking critically about the nature and effects of FBV in, for example, realisations of the possible critical effects of such policies on pupils and their families, which may reflect media reports of such actual effects. There is thus hope that a diversity of views could open spaces for critical debate between students. But there is also fear that teacher educators may miss or wilfully ignore this opportunity, given plans afoot by Ofsted to introduce Prevent training into teacher education. It is possible that organisations currently providing WRAP training in schools may be handed responsibility for student teachers' understanding of FBV. It is therefore possible that course leaders, relieved of no longer being (entirely) responsible for this contentious aspect, may consider this training sufficient emphasis. Students will then qualify as teachers without any critical understanding of the history of the political development of the notion of Britishness, or of the slippage 'that equates national identity with a common identity and the assertion of cultural pluralism with an assault on the very character of what it means to be [British]' (Giroux 1995, 47). In short, we may witness the collapsing of discussions on identity to assertions about security. 
Teacher educators might also seek solace from the fact that there is no pattern of increased overt hostility to Muslims or immigrants in students' responses from 2014 onwards, in contrast to the current social climate and reflected in the recent changes to education policy. In fact there is very little evidence of any such overt hostility anywhere within the responses. But of course that does not mean such hostility does not exist. Such prejudices surfaced very recently in a workshop on philosophy for children given by a colleague, in which in response to a question from the facilitator as to reasons for the lack of quality discussion, students replied that it was because they weren't allowed to say what they really felt about 'immigrants' on this course. The fact that student teachers so early in their development deem appropriate professional behaviour to mean not naming those they signal as existing in their imaginations, is arguably akin to that which Frankenburg (1996) refers to as colour and power evasiveness. This condition, similar to colour-blindness, but which affords more agency to the person looking (or not) at race, is certainly not desirable. As Omi and Winant (1994, 159) argue, 'opposing race requires that we notice race, not ignore it'. In this sense, the analysis is entirely predictable, given overwhelming evidence of the pervasiveness of colourblindness as a manifestation of whiteness within teacher education (e.g. Bell 2002; Lander 2011; Levine-Rasky 2000; Mazzei 2008; McIntyre 1997; Ulluci \& Battey 2011). The 'not naming' phenomenon identified here must therefore be understood by teacher educators as a mechanism to avoid challenges to 'the state, the institutions of civil society, and ourselves as individuals to combat the legacy of inequality and injustice inherited from the past and continually reproduced in the present' (Omi and Winant 1994, 159). In effect, therefore, this study suggests that even if student teachers arrive with the knowledge that being a professional means not emulating the seemingly relentless, sometimes crude and polarising racist nativist discourse offered by both the media and politicians, it does not mean that they are educated to resist it. 


\section{Bibliography}

Baker, Paul, Costas Gabrielatos, and Tony McEnery. 2013. "Sketching Muslims: A Corpus Driven Analysis of Representations Around the Word 'Muslim' in the British Press 19982009." Applied Linguistics 34 (3): 255-278. doi:10.1093/applin/ams048.

Bell, L. A. 2002. Sincere fictions: The pedagogical challenges of preparing white teachers for multicultural classrooms. Equity and Excellence in Education, 35 (3): 236-244. doi: $10.1080 / 713845317$.

Blinder, Scott, and W.L. Allen. 2016. "Constructing Immigrants: Portrayals of Migrant Groups in British National Newspapers, 2010 - 2012.” International Migration Review 50 (1): 3-40. doi: 10.1111/imre.12206.

Bonnett, A. 2008 Whiteness and the West. In New Geographies of Race and Racism, eds. C. Dwyer and C. Bressey, 17-28. Aldershot: Ashgate Publishing Ltd.

Cameron, D. 2011. PM's speech at Munich Security Conference. Gov.UK, February 2011. https://www.gov.uk/government/speeches/pms-speech-at-munich-security-conference

Cameron, D. 2014. British values. Gov.UK, June 2014. https://www.gov.uk/government/news/british-values-article-by-david-cameron

Clarke, P. 2014. Report into allegations concerning Birmingham schools arising from the 'Trojan Horse' letter. London: House of Commons.

Colley, L. 1992. Britishness and Otherness: An Argument. Journal of British Studies, 31 (4): 309-329. doi: http://dx.doi.org/10.1086/386013.

Department for Communities and Local Government 2015. Final Draft Letter to Mosques. Available: 
https://www.gov.uk/government/uploads/system/uploads/attachment_data/file/396312/16011

5_Final_Draft_Letter_to_Mosques_PDF.pdf

DfE Department for Education (2014a). Statistical First Release Teacher Workforce in England 2013.

Available:

https://www.gov.uk/government/uploads/system/uploads/attachment_data/file/335413/sfr11_ 2014_updated_july.pdf

Dickens, J. 2015. Ofsted Wants More Anti-Extremism Training. Schools Week. November: 8.

Fox, J.E., L. Morosanu, L. E. Szillassy. 2012. The Racialization of the New European Migration to the UK. Sociology 46 (4): 680-695. doi: 10.1177/0038038511425558.

Frankenberg, Ruth. 1996. Whiteness as an 'Unmarked' Category. In The Meaning of Difference: American Constructions of Race, Sex and Gender, Social Class, and Sexual Orientation, eds. K. Rosenblum and T. Travis, 62-68. New York: McGraw-Hill.

Galindo, R. and Vigil, J. 2006. Are Anti-immigrant Statements Racist or Nativist? What Difference Does it Make? Latino Studies. 4 (4): 419-447. doi: http://dx.doi.org/10.1057/palgrave.1st.8600224

Gilroy, P (2012) ‘My Britain is fuck all' zombie multiculturalism and the race politics of citizenship. Identities: Global Studies in Culture and Power. 19 (4): 380-397. doi:

$10.1080 / 1070289 X .2012 .725512$

Giroux, H.A. 1995. National Identity and the Politics of Multiculturalism. College Literature 22 (2): $42-57$.

Higham, J. 1955. Strangers in the Land: Patterns of American Nativism, 1860-1925. New Brunswick: Rutgers University Press. 
Jaret, C. 1999. Troubled by Newcomers: Anti-immigrant attitudes and Action during two eras of mass immigration to the United States. Journal of American Ethnic History 18 (9): 9-39. Kershaw, I. 2014. Investigation Report Trojan Horse Letter. Eversheds LLP: London. KhosraviNik, Majid. "The Representation of refugees, asylum seekers and immigrants in British newspapers during the Balkan conflict (199) and the British general election (2005)." Discourse and Society 20 (4): 477- 498. doi: 10.1177/0957926509104024.

KhosraviNik, Majid. 2010. The representation of refugees, asylum seekers and immigrants in British newspapers: A critical discourse analysis. Journal of Language and Politics 9 (1): 128. doi: http://dx.doi.org/10.1075/jlp.9.1.01kho.

KhosraviNik, Majid. 2014. "Immigration Discourses and Critical Discourse Analysis:

Dynamics of World Events and Immigration Representations in the British Press". In Contemporary Critical Discourse Studies, edited by Christopher Hart, 503-521. London: Bloomsbury.

KhosraviNik, Majid, Michal Krzyzanowski, and Ruth Wodak. 2012. "Dynamics of Representation in Discourse: Immigrants in the British Press." In Migrations: Interdisciplinary Perspectives, edited by Michi Messer, 283-295. Heidelburg, Germany: Springer

Kudnani, A. 2007. Integrationism: the politics of anti-Muslim racism. Race and Class 48 (4): 24-44. doi: 10.1177/0306396807077069.

Ladson-Billings, G. (1998) Just What is Critical Race Theory and What's It Doing in a Nice Field Like Education? International Journal of Qualitative Studies in Education 11(1): 7-24. doi: $10.1080 / 095183998236863$.

Lander, V. (2011) Race, culture and all that: an exploration of the perspectives of White secondary student teachers about race equality issues in their initial teacher education. Race, Ethnicity and Education, 14(3): 351-364. doi: 10.1080/13613324.2010.543389 
Levine-Rasky, C. 2000. Framing whiteness: Working through the tensions in introducing whiteness to educators. Race, Ethnicity and Education 3 (3): 271-92. doi:10.1080/713693039

Lippard, C.D. 2011. Racist nativism in the $21^{\text {st }}$ Century. Sociology Compass, 5(7): 591-606. doi: 10.1111/j.1751-9020.2011.00387.x

Macedo, D. and Bartolomé, L.I. (2014) Multiculturalism Permitted in English Only. International Multilingual Research Journal 8(1): 24-37. doi:

$10.1080 / 19313152.2014 .852426$

Matthews, Jamie. 2015. "Framing alleged Islamist plots: a case study of British press coverage since 9/11.” Critical Studies on Terrorism, 8 (2): 266-283, DOI:

$10.1080 / 17539153.2015 .1042305$

Mazzei, L. (2008). Silence speaks: Whiteness revealed in the absence of voice. Teaching and Teacher Education, 24(5): 1125-1136. doi:10.1016/j.tate.2007.02.009

McIntyre, A. 1997. Making meaning of whiteness: Exploring racial identity with white teachers. New York: State University of New York Press.

Morgan N 2014. Oral statement by Nicky Morgan on the 'Trojan Horse' letter. Gov.UK, July 2014. https://www.gov.uk/government/speeches/oral-statement-by-nicky-morgan-on-the$\underline{\text { trojan-horse-letter }}$

Nickels, H. C., L. Thomas, M. J. Hickman, and S. Silvestri. 2012. "De/Constructing 'Suspect Communities'.” Journalism Studies, 13 (3): 340-355. doi:10.1080/1461670X.2011.616412. Omi, M. and Winant, H. 1994. Racial Formation in the United States: From the 1960s to the 1990s. Rev. ed. New York: Routledge.

Omi, M. and Winant, H. 2015. $3^{\text {rd }}$ Ed. Racial Formation in the United States. Routledge: New York. 
Pérez Huber, L.P., Lopez, C.B., Malagon, M.C., Velez, V. and Solorzano, D.G. 2008. Getting beyond the 'symptom', acknowledging the 'disease': theorizing racist nativism. Contemporary Justice Review 11(1): 39-51. doi: 10.1080/10282580701850397

Pérez Huber, L.P. 2011. Discourses of Racist Nativism in California Public Education: English Dominance as Racist Nativist Microagressions. Educational Studies. 47: 379-401. doi: 10.1080/00131946.2011.589301

Rizvi, F. 2005. Representations of Islam and Education for Justice. In Race, Identity, and Representation in Education. $2^{\text {nd }}$ Ed., eds. C. McCarthy, W. Crichlow, G. Dimitriadis and N. Dolby, 167-178. New York: Routledge.

Sanchez, G.T. 1997. Face the Nation: Race, Immigration, and the Rise of nativism in Late Twentieth Century America. The International Migration Review. 31 (4): 1009-1030. doi: $10.2307 / 2547422$.

Steuter, E. \& Wills, D. (2010) 'The vermin have struck again': dehumanizing the enemy in post 9/11 media representations. Media, War \& Conflict. 3 (2): 152-167. doi: $10.1177 / 1750635210360082$.

Ulluci, K., and D. Battey 2011. "Exposing color blindness/grounding color consciousness: Challenges for teacher education". Urban Education 46 (6): 1195-1225. doi: 10.1177/0042085911413150.

van Dijk, T.A. 1988. News analysis: Case studies of international and national news in the press. Hillsdale, NJ: Lawrence Erlbaum Associates, Inc van Dijk, T. A. 1991. Racism and the Press. London: Routledge van Dijk, T. A. 1993. Elite discourse and racism. Newbury Park, CA: Sage. van Dijk, T. A. 2016. Racism and the Press. $2^{\text {nd }}$ ed. Oxon: Routledge. 
Table 1

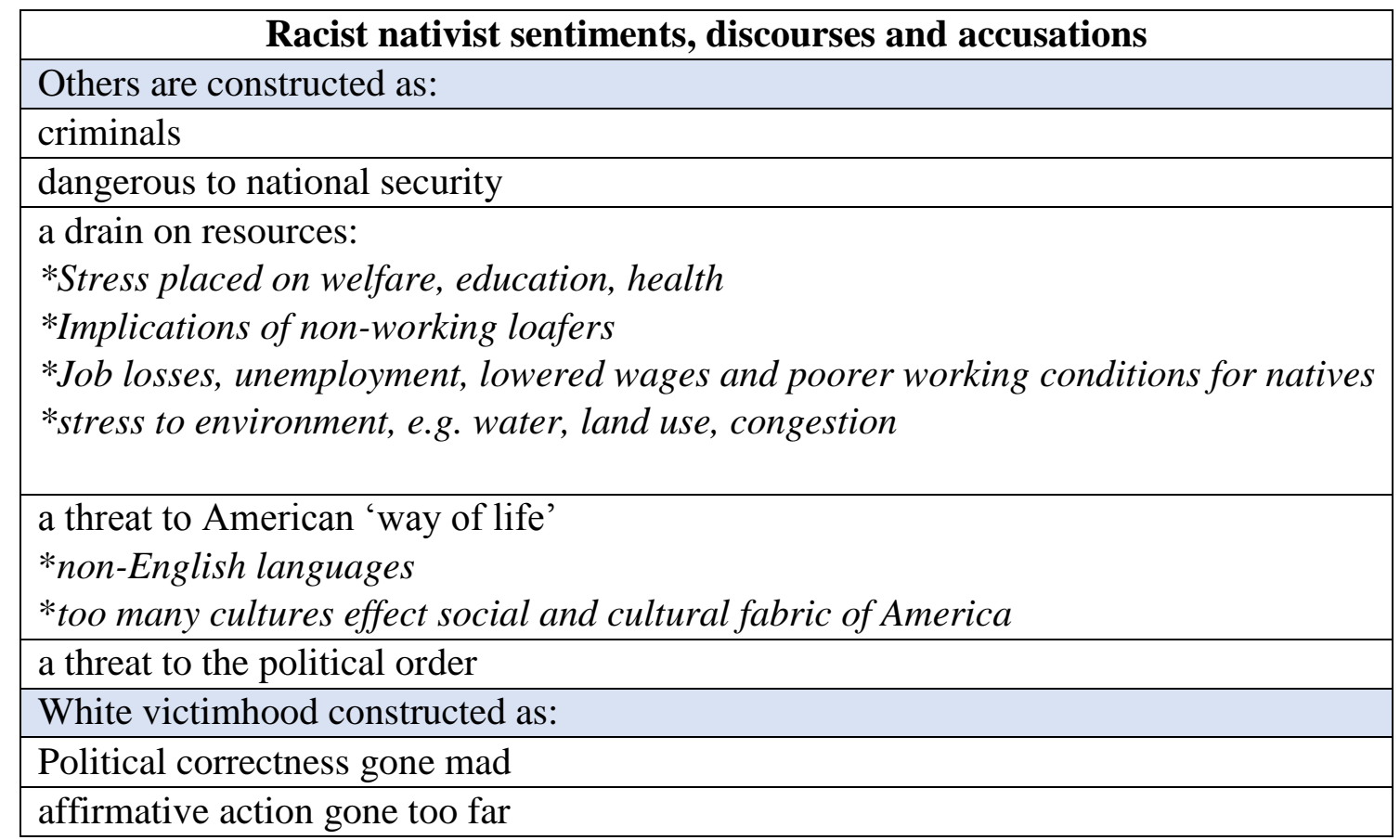

